\title{
SOILS WITHIN THE POST-2015 SUSTAINABLE \\ DEVELOPMENT AGENDA
}

Luca MONTANARELLA ${ }^{1}$

UDK 631.4:502.1

\begin{abstract}
Soils are considered across the Rio Conventions and while some advances have been made in the past two decades, implementation remains lacking and soil-related issues persist. This calls for a more integrated approach for the implementation of the Conventions. Similarly, soils will play a key role to achieve the post-2015 development agenda and can be found across the proposed Sustainable Development Goals (SDGs). This cross-cutting role is not being sufficiently acknowledged in the negotiations. Putting soils on the policy agenda will depend on a major shift in the discussion to recognize that soils underpin a wide range of services and should, therefore, be protected for future generations. Concerted efforts for advocacy within the post-2015 development agenda need to focus on keeping soils on the agenda and on making proposals for the effective implementation and monitoring of the SDGs.
\end{abstract}

Keywords: soils, political advocacy, sustainable development goals, UNCCD, UNCBD, UNFCCC

\section{INTRODUCTION}

Albeit being essential to sustainable development, soils have never been the specific focus of a Multilateral Environmental Agreement (MEA). However, as a crosscutting theme they are considered within the three Rio Conventions as they can contribute to climate change mitigation, they hold a large pool of biodiversity and are continuously affected by desertification. The three "Rio Conventions" are the United Nations Framework Convention on Climate Change (UNFCCC), the United Nations Convention on Biological Diversity (CBD) and the United Nations Convention to Combat Desertification (UNCCD). These MEAs were negotiated at the United Nations Conference on Environment and Development (UNCED) in Rio de Janeiro in 1992. As the main binding global environmental agreements they are considered the framework in which the countries of the world can implement sustainable development initiatives aiming at the

\footnotetext{
${ }^{1}$ Joint Research Centre, Via E. Fermi, 2749, I-21027 Ispra (VA), Italy, luca.montanarella@jrc.ec.europa.eu, http://eusoils.jrc.it/index.html,http://esdac.jrc.ec.europa.eu/
} 
reduction of human induced climate change, the protection of biological diversity and the limitation of desertification processes in drylands.

Putting soils on the agenda of these MEAs has involved a long process that required a large effort of awareness-raising and communication of issues related to the degradation of soils and land by scientists, civil society organizations and policy-makers. The convention texts of CBD and UNFCCC leave out soils but they are addressed in the text of the UNCCD and on the actions prescribed by the tree conventions such as the development of national action plans and the definition of specific targets and indicators for the monitoring of these resources at national level.

Twenty years after the conference in Rio we could take stock of the achievements at the Rio+20 meeting on sustainable development in 2012 in Rio de Janeiro. Indeed, some progress has been made but we are still observing extensive land and soil degradation processes in the world and we are rapidly depleting fertile soil resources that can be used for food production [1]. Conscious of these alarming trends, countries participating at the Rio+20 sustainable development conference agreed in the outcome document "The Future We Want" that we should "strive to achieve a land-degradation-neutral world in the context of sustainable development" [2]. A wide discussion on the definition of this concept and the concern of it potentially leading to the offsetting of land degradation in one place by restoration actions in another was triggered amongst scientists and on the political level amongst Member States in the framework of the process to set a Post-2015 development agenda and the proposed Sustainable Development Goals (SDGs) [3] to be signed off by the UN General Assembly in 2015. This soft law process follows the premise of the preceding Millennium Development Goals [2] and goes beyond by corresponding to the growing interest in the development of a universal and transformative agenda that provides a framing and a global vision for sustainable development that links environmental and development issues.

The aim of this article is to provide a review of current approaches of the three Rio Conventions to address soils and land and efforts to integrate soils and land in the Post-2015 process and the SDGs. We aim towards addressing the scientific community as well as the policy makers, attempting to bridge between policy and science by translating available scientific knowledge to potential policy recommendations. Some reviews of the provisions that address soils in international and national law have been made [4] [5] [42-44], but there has not been a comprehensive assessment of their integration in the political debate at the global level, in particular in the three Rio Conventions and especially linked to their role in the Post-2015 development agenda and the proposed SDGs. The following sections will discuss the links between soil resources and the conventions on climate change, biodiversity and desertification. These resources should be integrated in the conventions but are only partially or indirectly addressed. It seems that the SDGs offer an important opportunity to highlight the underpinning role of soil resources for sustainable development across the different themes. 


\section{SOILS AND CLIMATE CHANGE}

Soils hold the second largest carbon pool on earth after the oceans. Estimates of the organic carbon pool vary globally between 1463 and $2011 \mathrm{Gt}$ in the top $1 \mathrm{~m}$ of soil. This is due to the lack of reliable and updated global soil data since not all countries have monitoring systems, there are difficulties presented by the lack of comparability, temporal variability and the costs associated to obtaining the data [6]. This large carbon pool is in a constant equilibrium with the other pools and is highly sensitive to land use changes [7]. Any disturbance of the soil that increases mineralization rates of the carbon pool will cause a decrease of the carbon in the soil and the emission of carbon dioxide to the atmosphere [8]. For instance, agricultural practices that involve tillage will cause a rapid decrease of soil organic carbon levels. Lal [9] provides a comprehensive overview of the relevance of the soil organic carbon pool for climate change and potential implications of land use changes on greenhouse gas emissions.

The UNFCCC, adopted in 1992, aims to stabilize greenhouse gas emissions " at a level that would prevent dangerous anthropogenic (human induced) interference with the climate system"' [10]. According to fifth assessment report of the Intergovernmental Panel on Climate Change (IPCC) [11], an important mitigation measure is to increase the size of existing carbon pools, thereby extracting $\mathrm{CO}_{2}$ from the atmosphere (e.g., afforestation, reforestation and carbon sequestration in soils).

Overall, protecting and building-up the carbon stock of soils to avoid its release into the atmosphere can substantially contribute to climate change mitigation. Unfortunately, during the UNFCCC negotiations and the subsequent adoption of the Kyoto protocol the soil organic carbon pool has remained rather neglected. Only in recent years has there been a growing attention to peatlands, and very recently [45] to the potential of agricultural soils for climate change mitigation. The strong interest in peatlands and organic soils is because they account for the largest proportion of soil organic carbon and because these soils are particularly sensitive to climate change and land use changes [12]. Organic soils in boreal areas, mainly in Russia and Canada, are of major concern. This is due to the changes in permafrost-affected areas and the related possibility of rapid mineralization of large organic carbon pools within peatlands under permafrost conditions. Permafrost underlies 24 per cent of the northern hemisphere, can be over 2.5 million years old and up to $1,600 \mathrm{~m}$ deep [13]. It has an active layer which freezes and thaws each year. Warming is causing increased permafrost thaw, and the depth of the active layer in carbon-rich regions is projected to increase, causing land subsidence and coastal erosion, and ultimately increased release of carbon. Although there are large uncertainties involved in current thermal models estimating permafrost extent and thaw, there is clear agreement that permafrost coverage will decrease this century, and fluxes of carbon from thawing permafrost by 2100 are estimated between 1.2 and $1.6 \mathrm{Gt}$ C/year (equivalent to half of all fossil fuel emissions from the industrial age to today). Of particular concern in this context is obviously the possibility of large methane emission, a gas with much higher greenhouse potential then carbon dioxide [14]. 
Parties to the UNFCCC agreed to take precautionary measures, to develop and implement policies and programs to reduce greenhouse gas emissions, to provide support to developing countries and to report annual inventories of emissions [11]. Under the Kyoto protocol [15], industrialized nations (except the US) agreed on reductions on emissions. In addition, Parties recognized the importance of addressing unsustainable land use changes but unfortunately soils were not defined as a priority. Article 12 of the Kyoto Protocol further sets a Clean Development Mechanism through which countries in Annex I earn "certified emissions reductions" through projects implemented in developing countries. These include projects for afforestation and reforestation.

The Conference of the Parties (COP) has over the years struggled to achieve concrete commitments and the implementation of measures that force Parties to cut back their greenhouse gas emissions to a level equal or below the levels in the year 1990. Some stakeholders in this process complain about the, so far, rather shallow provisions and commitments made by States. Many were disappointed when Parties met in Bali in 2007, Copenhagen in 2009, Cancun in 2010 and again in Durban in 2011 [16] [17] only to produce more 'hot air' provisions and commitments [16]. The so-called breakthrough climate agreement between the US and China to curb carbon emissions seems to show a new leadership from the highest emitting countries, largely uncommitted in the negotiations until now. In addition, recent discussions in Lima, Peru which shifted the focus from emission caps to 'voluntary contributions', are believed to have renewed momentum for the negotiation of a new global climate agreement to limit the temperature rise to $2^{\circ} \mathrm{C}$ which is expected to be reached at COP21 meeting in Paris 2015. Soils should play a role in these discussions for their potential role in global mitigation efforts. The French Government has recently announced [45], in preparation of COP 21 of UNFCCC, the 'establishment of an international research program, which aims to develop agronomic research to improve organic matter stocks at an annual rate of 4 per 1000. Such an increase would offset emissions of greenhouse gases on the planet' and it was also mentioned in a press conference that this research program would lead to an 'action plan contributing to the agenda of solutions promoted by COP21' helping to 'reconcile food security objectives and the fight against climate change'.

\section{SOILS AND BIODIVERSITY}

Reductions in soil biodiversity make soils more vulnerable to other degradation processes. Therefore, soil biodiversity is often used as an overall indicator of the state of soil health. Although the complexity of soil biodiversity dynamics is not yet fully understood, there is evidence that biological activity in soils is largely dependent on the occurrence of appropriate levels of organic matter. The quantification of soil biodiversity is extremely limited and confined to projects of local relevance. As the main effects of loss of biodiversity are indirect, the estimation of its economic costs is still rather difficult, but nevertheless some recent estimates [18] are available. These conservative estimates show the annual value of ecosystem services provided by soil 
biodiversity to be $\$ 1.5$ trillion. This amount rises to $\$ 13$ trillion once ecosystem good such as crops and timber are included. This demonstrates the vast economic benefits of soil biodiversity and its conservation. Preventing the decline of soil biodiversity must therefore be of paramount importance and it has understandably continuously gained relevance in dialogues connected to the $\mathrm{CBD}$.

The CBD, which came into force in 1993, aims at the conservation of biological diversity, the sustainable use of its components and the fair, equitable sharing of the benefits arising from the utilization of genetic resources. The convention in its preamble frames the conservation of biodiversity as a common concern for humankind [19], which lays the foundation for the conservation of soil biodiversity globally. The role of soils in the convention text is almost non-existent which is surprising since soil is the habitat for an enormous variety of living organisms [20]. One gram of soil in good condition can contain up to 600 million bacteria belonging to 15,000 to 20,000 different species. In a pasture, for each 1 to 1.5 tons of biomass living on the soil (livestock and grass), about 25 tons of biomass (bacteria, earthworms and so on) are in the first $30 \mathrm{~cm}$ of soil underneath. Soil bacteria, fungi, protozoa and other small organisms play an essential role in maintaining the physical and biochemical properties needed for soil fertility. Larger organisms, worms, snails and small arthropods break up organic matter which is further degraded by microorganisms, and both carry it to deeper layers of soil, where it is more stable. Furthermore, soil organisms themselves serve as reservoirs of nutrients, suppress external pathogens and break down pollutants into simpler, often less harmful components [21] [22].

Actions prescribed under the $\mathrm{CBD}$, however, do provide the basis for the protection of soil biodiversity. Under the convention, countries must develop national programmes strategies, plans or programmes for the conservation and sustainable use of biological diversity or adapt for this purpose existing strategies, plan or programmes [19]. This is important as the convention recognizes soils as the most important source of land-related biodiversity. Additionally, under article 7 of the Convention [19], a member country needs to identify activities likely to have adverse effects on biodiversity and monitor their impacts through sampling and other techniques in order to establish an information management system. Article 8 [19], also sets provisions that help achieve the Convention's conservation goals. Here, Parties are required to establish a system of protected areas where special measures need to be taken to conserve biological diversity. These provisions can be used to put areas of ecological importance under special conservation regimes. Also, under article 8f, Parties are to rehabilitate degraded ecosystems and article 10d requires Parties to support local populations to develop and implement remedial action in degraded areas where biological diversity has been reduced. These provisions foster the implementation of sustainable land management practices, especially in geographical areas where soil biodiversity has been negatively affected.

Several initiatives have put soils on the biodiversity agenda. The COP of the CBD at its $6^{\text {th }}$ meeting in Nairobi April 2002 decided (COP decision VI/5, paragraph 13) "to 
establish an International Initiative for the Conservation and Sustainable Use of Soil Biodiversity as a cross-cutting initiative within the programme of work on agricultural biodiversity, and invites the Food and Agriculture Organization of the United Nations, and other relevant organizations, to facilitate and coordinate this initiative". Following this decision, a series of activities where initiated by FAO. More recently the European Commission, as one of the priority actions took up the topic for the EU Soil Thematic Strategy [23]. As a contribution to the 2010 International Year of Biodiversity the first Atlas of European Soil Biodiversity [20] was published by the European Commission and presented at the CBD COP 10 in Aichi, Japan, October 2010. This first comprehensive regional assessment on soil biodiversity has generated large interest and triggered the establishment of the Global Soil Biodiversity Initiative (GSBI) [24]. The GSBI is currently completing a Global Soil Biodiversity Atlas planned to be released during the International Year of Soils 2015. In addition, at its COP 10, the CBD launched a ten-year framework for action and a set of 20 biodiversity targets called Aichi targets [25] in order to renew and strengthen national efforts towards the conservation of biodiversity. Two of the Aichi targets have a direct link to the protection of soils. Target 7 deals with the sustainable management of areas under agriculture, aquaculture and forestry and target 15 aims to enhance ecosystem resilience and the contribution of biodiversity to carbon stocks through conservation and restoration, including the restoration of at least 15 per cent of degraded ecosystems.

\section{SOILS AND DESERTIFICATION}

The UNCCD is certainly the Rio Convention closest to the issue of global soil protection; however, it addresses a subset of soil issues and only in particular regions. The role of soils within the convention has been well recognized in the original version of the convention text which came into force in 1996, identifying the process of land degradation as "a reduction or loss, in arid, semi-arid and dry sub-humid areas, of the biological or economic productivity and complexity of rain fed cropland, irrigated cropland, or range, pasture, forest, and woodlands resulting from land uses or from a process or combination of processes, including processes arising from human activities and habitation patterns, such as soil erosion caused by wind and/or water; a deterioration of the physical, chemical, and biological or economic properties of soil; and a long-term loss of natural vegetation" (article 1f) [26].

The UNCCD was the global response to the pressing need to address severe desertification processes in Sub-Saharan Africa and in other drylands of the world and was expressively negotiated to address land degradation, including soil degradation, in those regions with a focus on social and economic as much as on environmental issues. Land degradation is estimated to affect $10-20 \%$ of the world's drylands [27]. Its limited focus on drylands has been perceived already in its early stage of implementation as a serious limitation, especially in view of the objective difficulty of describing in stringent and quantitative terms the area of applicability and the scope of the convention. 
Drylands are shifting due to climate change and land degradation is by now perceived as a global problem extending well beyond the original scope of the convention. Expanding the scope of the convention to cover other issue areas has been met by resistance from member states and parallel discussions on the possibility of creating a standalone convention for soils have not gained sufficient momentum.

The UNCCD does not include provisions nor does it offer guidelines for the development of national legislations for the protection of land. Altogether, it focuses on project implementation and a bottom-up approach, the building of partnerships and capacity building which includes the support of non-affected parties to countries suffering from desertification. Parties to the UNCCD that have declared themselves as affected by desertification are required to develop National Action Programs (NAPs) to combat desertification (articles 9-10, 19) which should focus on underlying causes, especially socioeconomic factors (article 5 para c) [26].

The consistent application of the convention in the affected countries should result in a measurable reduction of land degradation. Unfortunately, 20 years after ratification we are still struggling with serious soil degradation processes, not only in affected countries, but in most parts of the world. There is therefore an urgent need to review the implementation of the convention and move towards a new strategy of implementation.

A positive outcome of the discussions at the Rio +20 Conference, which can be attributed to awareness raising efforts made by the UNCCD Secretariat and its partners, was the proclamation of the common wish to achieve a "land degradation neutral world" [28]. This agreement has triggered a lively debate [29] in the context of the post-2015 implementation of the convention with the setting up of an intergovernmental working group to work on a definition for land degradation neutrality and to develop strategies for its implementation within the framework of the convention [30] [31]. Moreover, within the negotiations for the emerging post-2015 development agenda and the SDGs, land and soils play a role.

\section{SOILS AND THE POST-2015 DEVELOPMENT AGENDA}

The Rio +20 sustainable development conference launched a process to develop a post2015 development agenda [2]. This agenda is expected to provide an umbrella vision for sustainable development, define clear means of implementation and set structures and tools for the effective monitoring of sustainable development-related actions. A key element of this process is the development of a set of SDGs. The SDGs aim to integrate the three dimensions of sustainable development (economic, social and environmental) and to consider different national circumstances [2]. The post-2015 development agenda can contribute to awareness-raising and the implementation of the principles addressed in, inter alia, the MEAs discussed in the previous sections. A positive outcome of the Millennium Development Goals, amongst some not so positive results, was their ability to raise awareness for key development issues and catalyse actions and resources to 
address these issues [32] [33]. Furthermore, non-binding or "soft law" instruments "embrace a broader range of actors (including scientific organizations, academic specialists, NGOs, and industry)" and often act as an essential step in consensusbuilding" [34].

In addition to the involvement of a wide range of actors, the process of putting soils on the post-2015 development agenda and the SDGs provides the opportunity to address soils within the frame of a wide set of sustainable development issues i.e. with a nexus approach. Soils are one of the main elements of sustainable development [35] and are highly interlinked with the achievement of food, water and energy security, amongst others. The role of soils for sustainable development was recognized by article 206 of the Rio+20 Outcome Document "The Future We Want" in the agreement to "strive to achieve a land degradation neutral world in the context of sustainable development" [2]. As a limited and (in human terms) non-renewable natural resource we need to manage soils in a sustainable way for future generations. It is therefore imperative that these resources are coherently integrated across the SDGs. The Open Working Group formed to draft SDGs published a set of 17 proposed goals and 169 targets [36]. Soils and land will underpin the achievement of the SDG agenda as a whole and play a direct role in at least 7 of the proposed SDGs:

Draft Sustainable Development Goals (SDGs) as proposed by the United Nations Open Working Group (OWG) on SDGs in July 2014 highlighting the SDGs with a direct link to soils and land:

1. End poverty in all its forms everywhere

2. End hunger, achieve food security and improved nutrition, and promote sustainable agriculture

3. Ensure healthy lives and promote well-being for all at all ages

4. Ensure inclusive and equitable quality education and promote life-long learning opportunities for all

5. Achieve gender equality and empower all women and girls

6. Ensure availability and sustainable management of water and sanitation for all

7. Ensure access to affordable, reliable, sustainable, and modern energy for all

8. Promote sustained, inclusive and sustainable economic growth, full and productive employment and decent work for all

9. Build resilient infrastructure, promote inclusive and sustainable industrialization and foster innovation

10. Reduce inequality within and among countries

11. Make cities and human settlements inclusive, safe, resilient and sustainable 
12. Ensure sustainable consumption and production patterns

13. Take urgent action to combat climate change and its impacts

14. Conserve and sustainably use the oceans, seas and marine resources for sustainable development

15. Protect, restore and promote sustainable use of terrestrial ecosystems, sustainably manage forests, combat desertification, and halt and reverse land degradation and halt biodiversity loss

16. Promote peaceful and inclusive societies for sustainable development, provide access to justice for all and build effective, accountable and inclusive institutions at all levels

17. Strengthen the means of implementation and revitalize the global partnership for sustainable development

Source: Outcome document of the Open Working Group on SDGs [34]

Soils and land are addressed, amongst others, under goals for food security, sustainable agriculture and the protection of terrestrial ecosystems. The goals address, for instance, the need to ensure equal access and control over land, especially for poor and vulnerable populations. Issues of soil quality and halting land degradation are covered but will need to be managed together with targets that aim to double agricultural productivity, which could lead to an intensified use and to further degradation. The protection of soils in the SDGs can at the same time support goals, for instance, for climate change through the conservation of soil carbon stocks, for biodiversity conservation, for water availability and for poverty reduction though the support of livelihoods of people working in agriculture. These resources are found across the agenda, but there will be potential conflicts and trade-offs that should be addressed in a cross-cutting manner. Furthermore, addressing soils in the SDGs will require knowledge-based development of appropriate indicators that can be applied locally without increasing the data collection burden of Member States. But beyond indicators, which can be very costly and difficult to monitor, there is the need for innovative monitoring systems around the world. It will be crucial for this process to include different stakeholders and scientific disciplines.

Several initiatives are advocating for soils to be a part of the post-2015 development agenda. This issue has been highlighted for example in the communication of the European Commission (EC) outlining Europe's development aspirations for the new SDGs [37]. The Institute for Advanced Sustainability Studies (IASS) in Germany and partners have been working for the integration of soils and land in the SDGs with a 'people-centred' and transdisciplinary approach [38]. Several country governments are also supporting the issue, for instance, Namibia and Iceland formed an informal interest group called "friends of desertification," which aims to maintain the momentum generated by Rio +20 around desertification, land degradation and drought in the context of post-2015 development 
agenda [39]. In order to have an impact on the official post-2015 process, it will be crucial that these organizations and groups cross-reference and present coordinated proposals, including collaboration with other stakeholders and initiatives.

\section{CONCLUSIONS}

Soil resources are covered across the Rio Conventions either in the text or through the implementation of actions prescribed by the conventions. This has contributed to increasing the momentum to speak about soils at the global level. However, even with the implementation of the conventions, we are still dealing with major challenges related to the degradation of land and soil resources. This is in part due to a lack of a crosscutting and integrated approach.

The SDG process further highlights the need for an integrated approach as soils and land are found across several goals and will play a key role for the achievement of the agenda. The underpinning role soils and land will play across the SDGs needs to be recognized. Putting soils on the agenda of the existing MEAs and the post-2015 development agenda requires a major shift in the discussion around soils as a limited, non-renewable, natural resource. There is the need to recognize that soils are underpinning a wide range of services crucial for sustainable development and should, therefore, be protected for future generations.

The main difficulty in introducing soils within such a global sustainability agenda is that soils are in large majority in private ownership and are perceived by most countries of the world a topic strictly limited to national sovereignty. Accepting globally binding targets and regulations affecting national soil resources is still perceived by some governments as a major interference. The transnational dimensions of soil protection and sustainable soil management are still not sufficiently understood and the objective evidence of such interlinkages is still limited [40]. Some of the first considerations around the bioenergy debate in relation to Indirect Land Use Changes (ILUC) have triggered some research [41] into the interlinkages between national decision-making and their effects on the soil resources of other nations, but detailed data are still lacking for a comprehensive assessment of such interlinkages.

Moving forward, there is a need to focus on improving the implementation of the Rio Conventions with regards to soils. This will include further developing and strengthening synergies amongst the conventions. Additionally, soil scientists need to exchange with different stakeholders from other scientific disciplines, policy-making and civil society to link soils to key sustainable development issues such as water and food security and sustainable agriculture, climate change, biodiversity and ecosystem protection. Concerted efforts for advocacy within the post-2015 development agenda need to focus on keeping soils and land on the agenda and looking beyond 2015 towards an effective implementation and monitoring of the SDGs. 


\section{REFERENCES}

** Outstanding interest and *special interest

(1) **FAO: The State of the World's Land and Water Resources for Food and Agriculture. FAO, 2011, Rome. Major new assessment of the available land and water resources for global food production, including projections of resource needs for projected global population increase.

(2) United Nations (UN). (2012). "The Future We Want." UN, A/RES/66/288 annex to resolution 66/288 of the UN General Assembly 27 July $2012.40 \mathrm{pp}$.

(3) UNITED NATIONS (2014). The Road to Dignity by 2030: Ending Poverty, Transforming All Lives and Protecting the Planet. Synthesis Report of the Secretary-General on the Post-2015 Agenda, 2014, New York. 4-6pp.

(4) The World Conservation Union - IUCN (2002) Legal and Institutional Frameworks for Sustainable Soils: A Preliminary Report. IUCN Environmental Policy and Law Paper No. 45. 2002.

(5) *Wyatt, A. (2008), The Dirt on International Environmental Law Regarding Soils: Is the Existing Regime Adequate?, 19 Duke Environmental Law \& Policy Forum 165-208. Provides an overview of soils in the Rio Conventions and explores the option of creating a convention for soils.

(6) Stockmann, U., Adams, M.A., Crawford, J.W., Field, D.J., Henakaarchchi, N., Jenkins, M., Minasny, B., McBratney, A.B., Courcelles, V.d.R.d., Singh, K., Wheeler, I., Abbott, L., Angers, D.A., Baldock, J., Bird, M., Brookes, P.C., Chenu, C., Jastrow, J.D., Lal, R., Lehmann, J.,O’Donnell, A.G., Parton, W.J., Whitehead, D., Zimmermann, M., 2013. The knowns, known unknowns and unknowns of sequestration of soil organic carbon. Agriculture, Ecosystems \& Environment 164(0), 80-99.

(7) Schlesinger, W.H. (1995). An overview of the global carbon cycle. In: Lal R, Kimble J, Levine E, Stewart BA (eds) Soils and global change. Lewis, Boca Raton, Florida, pp 9-25.

(8) Smith, P. (2012). Soils and climate change. Current Opinion in Environmental Sustainability 2012, 4:1-6.

(9) Lal, R. (2013). 3rd Global Soil Week, 19-23. April, 2013 Soils and the Carbon Cycle in Relation to Climate Change. Presentation at 2nd Global Soil Week, 2731. October 2013, Berlin, Germany. 52pp. http://globalsoilweek.org/

(10) United Nations Framework Convention on Climate Change - UNFCCC (1992), Convention on climate change. http://unfccc.int/files/essential_background/ background_publications_htmlpdf/application/pdf/conveng.pdf

(11) IPCC, 2014: Climate Change (2014), Mitigation of Climate Change. Contribution of Working Group III to the Fifth Assessment Report of the Intergovernmental Panel on Climate Change [Edenhofer, O., R. Pichs-Madruga, Y. Sokona, E. Farahani, S. Kadner, K. Seyboth, A. Adler, I. Baum, S. Brunner, P. Eickemeier, 
B. Kriemann, J. Savolainen, S. Schlömer, C. von Stechow, T. Zwickel and J.C. Minx (eds.)]. Cambridge University Press, Cambridge, United Kingdom and New York, NY, USA. 67 pp.

(12) FAO (2014): Towards climate-responsible peatland management. FAO, 2014, Rome, Italy.

(13) Jones, A., V. Stolbovoy, C. Tarnocai, G. Broll, O. Spaargaren and L. Montanarella (eds.), 2010, Soil Atlas of the Northern Circumpolar Region. European Commission, Office for Official Publications of the European Communities, Luxembourg. 142 pp.

(14) Tarnocai, C., Canadell, J.G., Schuur, E.A.G., Kuhry, P., Mazhitova, G., Zimov, S. 2009. Soil organic carbon pools in the northern circumpolar permafrost region, Global Biogeochemical Cycles, 23 (2): GB2023.

(15) Kyoto Protocol to the United Nations Framework Convention on Climate Change (1997), UN Doc FCCC/CP/1997/7/Add.1, Dec. 10, 1997; 37 ILM 22 (1998). http://unfecc.int/resource/docs/convkp/kpeng.pdf.

(16) Giddens, A. (2009), The politics of climate change: Polity. ISBN 9780745646930.

(17) Dessler, A, E; Parson, E. (2010), The science and politics of global climate change: a guide to the debate: Cambridge University Press. ISBN 9780521737401.

(18) Dominati, E., Patterson, M. and Mackay, A. (2010). 'A Framework for Classifying and Quantifying the Natural Capital and Ecosystem Services for Soils', Ecological Economics, 69, pp. 1858-1868.

(19) United Nations Convention on Biological Diversity - CBD (1992), 1760 U.N.T.S. 79 Convention Text. Available online at http://www.cbd.int/doc/legal/cbd-en.pdf, accessed on 07.01.14. 3pp., text article 6a, (last visited 07.01.2014).

(20) *Jeffery, S.; Gardi, C.; Jones, A.; Montanarella, L.; Marmo, L.; Miko, L.; Ritz, K.; Peres, G.; Römbke, J.; van der Putten, W. H. (eds); European Atlas of Soil Biodiversity. 2010; European Commission, Publications Office of the European Union, Luxembourg. Main reference work advocating the need to consider the large biodiversity pool existing below ground, not only in Europe but also at global scale.

(21) Bello H. S., Isa T., Isa M. A. and Akinmuisere K (2013): Effects of Land Use on the Nature and Populations of Microorganisms in the Semi-Arid Region of NorthEastern Nigeria. International Journal of Environment. Vol. 2.1. Sep-Nov 2013.

(22) European Commission (2001): The Soil Protection Communication - DG ENV Draft October 2001.http://www.ehu.eus/europeanclass2003/soilpaper.pdf

(23) European Commission: Thematic strategy for soil protection. COM (2006) 0231 Final. Commission of the European Communities, Brussels; 2006.

(24) GSBI (2012), White Paper on the First Open Meeting of the Global Soil Biodiversity Initiative (GSBI) Held in London, England, 30 March 2012, available at http://www.globalsoilbiodiversity.org/sites/default/files/WhitePaper_London201 2.pdf 
(25) United Nations Convention on Biological Diversity - CBD COP 10 Decision X/2 (2010), Strategic Plan for Biodiversity 2011-2020

(26) United Nations (1994): United Nations convention to combat desertification in those countries experiencing serious drought and/or desertification, particularly in Africa - final text of the convention. 1994, UNCCD, Bonn, Germany.

(27) Millennium Ecosystem Assessment, 2005a. Ecosystems and Human Well-being, vol 1. Current State and Trends: Findings of the Condition and Trends Working Millennium Ecosystem Assessment Series. Dryland Systems, Chapter 22, p. 815.

(28) **United Nations Convention to Combat Desertification (UNCCD) Policy Brief; Zero Net Land Degradation. 2012, Bonn, Germany. New initiative by UNCCD aiming towards setting a quantitative Sustainable Development Goal of zero net land degradation for discussion in the Rio +20 summit.

(29) Chasek, P., et al., Operationalizing Zero Net Land Degradation: The next stage in international efforts to combat desertification?, Journal of Arid Environments (2014), http://dx.doi.org/10.1016/j.jaridenv.2014.05.020.

(30) United Nations Convention to Combat Desertification - UNCCD COP (11)/19 Report on activities supporting the United Nations Decade for Deserts and the Fight against Desertification (2010-2020) http://www.unccd.int/Lists/ OfficialDocuments/cop11/19 eng.pdf UNCCD COP11 decision to establish an intergovernmental working group to: (1) establish a science-based definition of land degradation neutrality in arid, semi-arid and dry sub-humid areas; (2) develop options relating to arid, semi-arid and dry sub-humid areas that Parties might consider should they strive to achieve land degradation neutrality; and (3) advise the Convention on the implications for its current and future strategy, programmes and the resource requirements.

(31) **Thomas R.J., M. Akhtar-Schuster, L.C. Stringer, M.J. Marques, R. Escadafal, E. Abraham, G. Enne: Fertile ground? Options for a science-policy platform for land. Review Article Environmental Science \& Policy, Volume 16, February (2012), Pages 122-135.There is a gap in science-policy advice concerning land and soil at global scale. The main UN Convention dealing with this environmental compartment, the UNCCD, lacks adequate scientific advisory bodies to deliver the needed high level scientific advice and guidance. It is advocated the creation of a body similar to an Intergovernmental Panel on Soils (Land).

(32) United Nations (2013), Lessons Learned from MDG Monitoring From a Statistical Perspective Report of the Task Team on Lessons Learned from MDG Monitoring of the IAEG-MD. 2pp.

(33) United Nations (2013), A New Global Partnership: Eradicate Poverty and Transform Economies Through Sustainable Development The Report of the HighLevel Panel of Eminent Persons on the Post-2015 Development Agenda. 1-5pp.

(34) Hunter, D; Salzman J. \& Zaelke, D. (1991), Soft Law and the International Law of the Environment, 12 MICH. J. INT'L L. 420, 430. At 357 (citing Pierre-Marie Dupuy). 
(35) Hurni H, Giger M, and Meyer K (eds).: Soils on the global agenda. Developing international mechanisms for sustainable land management. Prepared with the support of an international group of specialists of the IASUS Working Group of the International Union of Soil Sciences (IUSS). 2006; Centre for Development and Environment, Bern, 64 pp.

(36) Open Working Group on the Sustainable Development Goals. Outcome Document (2014). Published on 19 July 2014. United Nations.

(37) European Comission (2014), Communication from the Commission to the European Parliament, the Council, the European Economic and Social Committee and the Committee of the Regions a Decent Life for all: from vision to collective action. COM (2014) 335 final. Brussels, 2.6.2014. 10pp.

(38) Ehlers, K., Lobos Alva, I., Montanarella, L. et al. (2013), Soils and Land in the SDGs and the Post-2015 Development Agenda: A proposal for a goal to achieve a Land Degradation Neutral World in the context of sustainable development. Available online at: http://globalsoilweek.org/thematic-areas/sustainable-developmentgoals/soil-and-land-in-the-post-2015-development-agenda, Last visited 09.01.2014.

(39) UNCCD (2013), News item of 06/09/2013: Iceland and Namibia Launch Group of Friends on Desertification http://www.unccd.int/en/mediacenter/MediaNews/ Pages/ highlightdetail.aspx?HighlightID $=222$, visited 09.01.2015.

(40) SERI (2011), EUROPE'S GLOBAL LAND DEMAND: A study on the actual land embodied in European imports and exports of agricultural and forestry products. http://seri.at/

(41) Kretschmer, B, Allen, B, Kieve, D, Smith, C. (2013). The sustainability of advanced biofuels in the EU: Assessing the sustainability of wastes, residues and other feedstocks set out in the European Commission's proposal on Indirect Land Use Change (ILUC). Biofuel ExChange briefing No 3. Institute for European Environmental Policy (IEEP), London.

(42) Bouma, J. 2014. Soil science contributions towards Sustainable Development Goals and their implementation: linking soil functions with ecosystem services. J.Plant Nutrition and Soil Sci. 177 (2): 111-120.

(43) Bouma, J., 2015. Engaging soil science in transdisciplinary research facing wicked problems in the information society. Soil Sci.Soc.Amer.J. 79: 454458.(doi:10.2136/ sssaj2014.11.0470).

(44) Bouma, J., C.Kwakernaak, A.Bonfante, J.J. Stoorvogel and L.W. Dekker. 2015. Soil science input in Transdisciplinary projects in the Netherlands and Italy. Geoderma Regional 5,96-105. (http://dx.doi.org/10.1016/j.geodrs.2015.04.002).

(45) Press release 'Contribution de l'agriculture à la lutte contre le changement climatique: Stéphane Le Foll annonce le lancement d'un projet de recherche international: le «4 pour 1000». MAAF, Paris, March 17, 2015. http://agriculture.gouv.fr/Cop21-le-4-pour-1000 


\section{List of Abbreviations}

$\begin{array}{ll}\text { MEA } & \text { - Multilateral Environmental Agreement } \\ \text { UNFCCC } & \text { - United Nations Framework Convention on Climate Change } \\ \text { CBD } & \text { - United Nations Convention on Biological Diversity } \\ \text { UNCCD } & \text { - United Nations Convention to Combat Desertification } \\ \text { UNCED } & \text { - United Nations Conference on Environment and Development } \\ \text { SDGs } & \text { - Sustainable Development Goals } \\ \text { IPCC } & \text { - Intergovernmental Panel on Climate Change } \\ \text { COP21 } & \text { - 2015 Paris Climate Conference } \\ \text { COP } & \text { - Conference of Parties } \\ \text { GSBI } & \text { - Global Soil Biodiversity Initiative } \\ \text { NAPs } & \text { - National Action Programs } \\ \text { OWG } & \text { - Open Working Group for the SDGs } \\ \text { EC } & \text { - European Commission } \\ \text { IASS } & \text { - Institute for Advanced Sustainability Studies } \\ \text { ILUC } & \text { - Indirect Land Use Changes }\end{array}$

